\title{
Mansour Fahmy, Pioneer of Islamic Feminism in Modern Egyptian Thought
}

\author{
Mahmoud Mohammed Ali \\ Assiut University, \\ 71515 Assiut, Arab Republic of Egypt, \\ dr.mahmoudali55eg@gmail.com
}

\begin{abstract}
Mansour Fahmy (1886-1959), one of the dramatic figures in modern Arab philosophical and social thought. He was the reformist and enlightenment figure in modern Arab history. He is also the owner of a notable current that was subjected to a violent attack that silenced him for a long time and forced him to "hide" physically. However, this did not eliminate the new opinions and positions that came at the beginning of the twentieth century towards the issue of women. He is the first to write with a scientific methodology - from the point of view of sociology - on Islamic discourse and its dealings with women. he sought to differentiate between religion and the religious establishment, between the personality of the Prophet Muhammad and what later prevailed in the books of jurisprudence and others. When he discussed the headscarf issue, he concluded that it was the product of traditions and customs that the Hijab is not from the Islamic religion. Islamic law has nothing to do with the Hijab. Mansour Fahmy's creativity was at one of the sensitive stages in Egypt's modern history in which the political, social, national, cultural, and revolution clashed in each one. All this, in turn, identified the problem of Mansour Fahmy's intellectual personality in the battles of thought and politics. This research's main task is to redraw the features of his actual personality and the reality of his intellectual, social, and political positions. Besides, this study seeks to uncover the effect of philosophy on crystallizing Mansour Fahmy's critical personality and its role in laying the foundations of the critical vision with its practical, reformist, and enlightening dimensions.
\end{abstract}

Keywords: Mansour Fahmy, feminism, Islamic feminism, Qassem Amin, Taha Hussein

\section{Article history:}

The article was submitted on 05.01.2021

The article was accepted on 10.03.2021

(C) Mahmoud M.A., 2021

(i) This work is licensed under a Creative Commons Attribution 4.0 International License https://creativecommons.org/licenses/by/4.0/ 
For citation: Mahmoud M.A. Mansour Fahmy, Pioneer of Islamic Feminism in Modern Egyptian Thought. RUDN Journal of Philosophy. 2021;25(2):202-212. DOI: 10.22363/23132302-2021-25-2-202-212

On the twenty-sixth of March 1959, Egypt and the whole Arab world lost one of the greatest intellectual thinkers and a pioneer of the modern renaissance, Dr. Mansour Fahmy. He was a thoughtful philosopher, a sensitive literate, well-read of the literary and philosophical ancestral heritage, and the modern European renaissance methods, one of the missionaries of faith, love for the country, seeking knowledge, social reform, and high moral standards. None of the present generation literates is unaware of this unique character that resembled the best resemblance of nobility, chivalry, and righteousness.

Our professor Bayoumi Madkour said about him, "I have known the deceased for a quarter of a century or more. I have known him as a professor and dean, an academician and colleague, a lecturer, a writer, and a researcher, a preacher, and a debater.

I knew him as a man who was enthusiastic about what he satisfied himself with. This enthusiasm did not weaken as he got old or as the days passed. When he was old, he used to take explicit actions that are dear to some young people. I knew him and learned from him to aim for and maintain a goal. If he got caught up in something, he would seek for it as much as he could.

I knew him as a man who was quick to speak and willing to address the audience and did not hesitate to raise his voice openly and firmly if he had the opportunity or if there was a reason to do so. I knew in him eloquence and perseverance in defending opinion. Many a time, I heard him defend certain views without getting tired of repetition or fearing stubborn opposition. In knowing him, I finally knew the Arab man who sticks to his Arabism and who defends his glories" [1].

Mohammed Tawfik Diyab also said about him, "He is a noble, great character fond of the Arabic language. He would get angry if someone attacked and vilified it. He would even get furious if honor was insulted or if religion was attacked. Thus, he is a man of intense emotion, unblemished enthusiasm and extremely sensitive." I have known you for fifty years. You sought knowledge in western countries. I got to know you, then we became friends, and I was pleased to become your brother. I wasn't concerned about you from any flaw. I found that you have not strayed from the path of good, rightness, and perfection. Today you would hear my failing and speechless words, but you attack my loyalty and the loyalty of those who gathered to greet you. Soon I will join you, and my modest soul would be pleased to meet your mighty spirit. Every forthcoming event is near [2].

Mahmoud Timor, in his book Features and Branches, tried to link between Mansour Fahmy's life and his philosophical ideas. He believes that Mansour Fahmy's life and mentality are strongly connected to what he studies of philosophy and its dictionaries, especially its moral side. His philosophy was about good and 
evil in human nature and how a man can do more good and avoid evil by adhering to the codes of morality [3. P. 84].

In the fifth part of his book From a Distance, Taha Hussein, who had many debates with Mansour Fahmy, illustrates the impact of Mansour Fahmy's French culture and philosophical and social studies on his writings. He showed that Fahmy was influenced by two groups of philosophers: the 18th-century French philosophers and the social philosophers of the late last century and beginning of this century, such as Russo, the man of precise sentiment, powerful emotions, turbulent blending, and fruitful fiction and Durkheim the man of straight mind and strict scientific approach. Taha Hussein says, "If I wanted to identify the influence of Russo on the thoughts of Mansour Fahmy, I would have pointed out this obvious ambition by showing an example higher than the good sought by Mansour as did Russo in the naïve free nature free from the corruption of civilization" [4. P. 99-100].

Mansour Fahmy was born in the middle of the 19th century in this painful Modern Egyptian History. We can divide his life into two clear stages ,as said Dr. Ibrahim Madkour: preparation and growth stage and maturity and production stage. The first stage lasted for thirty years, in which he first enrolled in the Primary school in Al-Mansoura near where he lived. Then, he moved to Cairo to continue his study in a private French school, where he got his secondary school degree in 1906. He was drawn by jurisprudence and legislation so that he enrolled in the Faculty of Law, where he had not stayed for long because the Egyptian University announced a mission for the study of Philosophy to Paris University. He applied and won its competition.

In 1908 he traveled to Europe, where he stayed for five years sipping from the spring of knowledge and literature. He was not convinced in the philosophical studies for which he traveled. However, he added to them some scientific studies such as natural geography, physiology, and embryology as if he wanted to continue the methods of social studies curriculum that was prevalent at the University of Sorbonne at that time. More than one scientist and philosopher schooled him. He was influenced explicitly by Lévy-Bruhl, one of the French social school leaders at the beginning of this century. His study was met with success, and he got his Ph.D. degree [1. P. 355].

His foreign readings have not distracted him from the Arabic cultural resources from which he sipped during his childhood and youth as he continued to refer to it throughout his entire life. Thus, he had an eastern culture and a western one. He mastered the French language as he did with the Arabic language. He became little familiar with English and French. All of these are tools suitable for research and study. Before he went back to Egypt, he was able to travel to some countries of Europe. Besides what he read and studied, he benefited from these travels [Ibid. P. 356].

Before moving on to the second stage of his life, I have to refer to his Ph.D. dissertation, which was about The Status of the Woman in Islam (La condition de 
la femme dans l'Islamisme). It was natural for him to choose a topic like this when freeing the Egyptian woman led by Qassem Amin and his colleagues. However, the university that sent him on that mission saw that he wrote some phrases that were incompatible with the religious traditions, and it sought to prevent the presentation of his dissertation. Despite all of that, Mansour Fahmy was so enthusiastic about continuing till the end. His paper was published, and he received higher degrees of honors [Ibid. P. 357].

Mansour Fahmy presented his Ph.D. dissertation to the Sorbonne University in December 1913 under the title The Condition of Women in Islamic Tradition and Development which was issued later in France as a book The Condition of the Woman in Islam. It was not translated until 1997 and was published within the publications of Dar Al-Gamal (a translation by Farida Miqdady). It was the talk of the town at that time [5. P. 45].

The Egyptian woman had to clang to the heavy chains of the veil, which were not imposed on her by religion but by the impacts of the traditions of the late centuries of Muslims' lives. Free thinkers, as well as Ali Tahtawy and Qassem Amin, who were responsible for freeing the woman and establishing the Egyptian university, saw that the revival of the East and of the Muslims could be achieved only through the emancipation of women. The freethinkers who called for this liberation were opposed by the traditionalists who stick to such traditions. Qassem Amin got affected by this opposition [6. P. 178].

Mansour Fahmy was also affected by this opposition days before the discussion of his dissertation. A report was sent to the university that said that the dissertation is anti-Islamic and supervised by a Jewish professor (Lévy-Bruhl is the person in question). At that point, the university demanded to postpone the discussion, yet he did not listen, and it was discussed on time. After that, Fahmy returned to Egypt, and he was received by an opposition launched by government-friendly newspapers, members of Al-Azhar, and retrospective politicians. The accusations charged against him were that he was atheistic, an enemy of religion, a corruptor of the youth, and a tool for the Jewish conspiracy against Islam. He found himself fired from the Egyptian University at the end [7].

He was dismissed from his position for six years. He had not returned to his work until 1920 and found no other way but to hide in his village until the 1919 Revolution to try to return to the university. He returned on condition that he should apologize or, more precisely to repent for what his mind committed. He submissively said, "It seems that I deviated a little bit as my knowledge of Islam was little, and when I was received in Egypt with a great sensation, I became more stubborn. I was destined to sit with some broadminded and knowledgeable sheiks. Thank God I began to get rid of the deviation and return to the barn of religion." He even criticized his dissertation in some articles that he published in some newspapers and periodicals [8].

When he returned to his work, he studied philosophy until the Egyptian University became a public university. Then, he became an assistant professor, a 
vice-dean, and a dean for the Faculty of Arts. He remained dean until he held the position of manager of House of Books. Then he was chosen as a president of the University of Alexandria, where he stayed until he was pensioned off in 1946 [9. P. 177].

In 1933 he was chosen as a member of the philological society. The following year he became its clerk and maintained that position until he passed away in 1959. Professor Mohammed Harby states, "The Conditions of Women in Islam is not a satirical article addressed against women in Islamic communities for the purpose of condemning and defaming their condition in front of the West. This book is a Ph.D. dissertation discussed at the University of Sorbonne in 1913, when Ph.D. dissertations represented a severe scientific work with all the characteristics of rigorous academic studies. This dissertation could have disappeared under the rubble of other university studies if it weren't for the guards of the old traditional system who attacked and took it out on it. Thus, they unknowingly defamed this work. It was made available for this work to see the light and spread among people" [Ibid. P. 178].

Mansour Fahmy got attacked as soon as he returned to Egypt. Some journalists that lack conscience defamed him and pitted the public against him to take revenge. It was a shame that some university authorities shamefully bowed to such false press campaigns and did nothing to defend one of its members, Mansour Fahmy. He was tried for a mean report which claims that the so-called Mansour Fahmy had discussed in France a Ph.D. dissertation contrary to Islam and its Prophet under the supervision of a Jewish professor named Lévy-Bruhl. This how Mansour Fahmy was persecuted and removed from university teaching in Egypt. He did not return to the university till after the revolution of 1919. It can be said that people forgot about him and did not exist as an intellect after his return. The strict control and social pressures destroyed him and his hopes and dreams in development and scientific research. Those who are unaware of the daily hatred for awareness in Islamic societies cannot understand the stream or fate of Mansour Fahmy. He was significantly mentally influenced after they had denied and despised his work. A list was not set for him after that, although he was a rising researcher who promises outstanding tender [10. P. 12].

Mansour Fahmy was not the first to present the condition of women and their problems. He was preceded by Qassem Amin (1865-1908) when he published in 1899 the first book in favor of setting women free. Indeed, some Syrians and Lebanese had already preceded him in doing so, but he was the first one to hold the giant scissors to tear up the veil that covers Arab women and prevents them from seeing the light. Mansour Fahmy acknowledges his credit for him, but he ventures further in the approach as he searches for the root of the Hadiths about the woman in the Islamic community during the first century and not for the mental or moral makeup of that individual or another. Society and not the individual is the base. Society establishes the Hadiths that fit, fights those that do not or hides them, or does not simply play by them. The same thing can be said about Maghrebian works, 
especially those of fundamentalism that talk about the condition of women out of only fighting the West or hating it. If the West is doing so, we should do the opposite [Ibid. P. 16].

We must not believe this situation as it is. There are thousands of young women raised in folksy communities and who received an Arab upbringing more than a European one but still fight for freedom without aiming their goal towards a western or European model. They rebel against the father's authority or the brother or the husband or simply against these ideological police represented by the TV or radio Mufti. He is a snooper of a new kind, and he is the first to call for a Salafist vision based on wardship, woman's veil, and her obedience to man. The second, on the other hand, defended the veil and polygamy [Ibid. P. 17].

Fahmy was the first one to write in a scientific methodology, from the point of view of sociology, about the Islamic preacher and his treatment of the woman while differentiating between religion and the religious establishment and the character of the Prophet of Islam as well as his sacred texts that contributed in one way or another to the position of the woman under Islam [Ibid. P. 19].

At that time, Mansour discussed several issues that no one could approach or even think about with unusual audacity. For instance, he discussed the Prophet's demand for the husbands who have multiple wives to achieve equality among their wives. Mansour states, "These precise rules in equality among wives were meant to limit polygamy. Here, Mohammed did not walk by the rules or apply them. Theoretically, the principle of equality between wives is mentioned in the Quran, but practically, Mohammed did not treat his wives, mothers of believers, equally. One day the Prophet's wives sent Fatima, one of his daughters, on a sensitive mission to her father. She said to her father, "your wives ask you to treat them like Aisha." It was hard for Mohamed, who was in love with Aisha, to bow to his wives' desires. Didn't Allah bless Mohamed forgiving all the mistakes he committed in his house by favoring one of his wives over the others? However, he was fair with his wives. He divided his time equally among them, but he did not defend himself for his love for Aisha. He confronted his God, justifying himself and saying, "This is what I have done concerning that over which I have control, do not blame me for that over which you have control, and I do not." In other words, Mohamed is the master of his time and properties as he can divide his time and what he owns equally among his wives while hearts belong to God, so he cannot control his emotions. $\mathrm{He}$ who allowed polygamy excluded himself from it. A Muslim man can only marry four wives, and every marriage has to take place in the presence of witnesses and payment of dowry to the wife. On the other hand, Mohammed married more than four and exempted himself from witnesses or dowry [Ibid. P. 22].

He also talked about the case of religion and social traditions as we can see that Fahmy differentiates between Muhammadism and the Islamic religion. The former is represented in Mohamed's faith in its initial pure form, while that latter means organizations of various origins that over time took the prestige of sacred laws. He asserts Mohammed's intense desire to protect the woman, but the religious 
institutions and theocratic laws led to the inferiority of the woman as such institutions and laws turned the authority of the father or household into a sacred one similar to that of God. This social and religious condition made the house the sole work for the woman as she had to keep herself to grief at home. Fahmy sees that although Islam gave the woman her character, we must confirm that the woman after Islam was found in a much more inferior position than it was before Islam. Even if she appeared to be inferior before Islam, she had a social presence as she would join conquests, work in trade, and had the right to embrace the religion she wants. However, after Islam, through the inconsistency of sacred scriptures, everything turned upside down. She was supposed to be in a better position, but she was much worse realistically and socially. After the victory of Islamic conquests, the character of the Arab woman has faded as well as her social value. Institutions of different sources such as polygamy, aristocracy, and theocracy are factors that combined to contribute to the gradual woman's humiliation [Ibid. P. 49].

There are similar texts of which we mention this one: one day, when Mohammed was busy spreading justice among people and solving their problems, a woman came to him complaining that her husband hit her and seeking his justice. In such situations, Mohammed applies the law of punishment (e.g., the bee law), but he hesitated to punish the accused husband with severe punishment, and God inspired Mohammed to legislate a law from which a man would benefit. The Quran states, "Men are the protectors and maintainers of women." In this way, the charge on the husband is dropped. This law still dwells in the mouths of believers and is used by men to prove their superiority over women. In a moment of meditation, Mohammed was thinking about the woman's condition, and it appears to him that many men became prominent in their lives, and a few women did [Ibid. P. 50].

What Mohammed said reminds us of what the priest, a member of the clergy, said, "Among a thousand men I found one while among all women I found no one." The Christian influence can be seen here, but this definitely does not prove that Mohammed said these words. The significance of these words is that they are considered part of the genuine Hadith [Ibid. P. 55].

He talked about the legend of the veil. Fahmy sees that the veil is the outcome of traditions and not religion. Islamic law has nothing to do with the veil. He also showed the relation between isolation, veil, and social class. The veil and isolation, for instance, were not imposed upon maids. The famous incident of Omar Ibn AlKhatab when he yelled at the veiled maid as she tried to look like free women. Thus, isolation and the veil discriminate free women as the honor of high-class girls from girls of the public. This thought developed from the legacy of a woman's isolation away from tribal war so that she won't get captivated or kidnapped as a booty. Wearing the veil was not universal as we have documents that point out that women in that period and Mohammed's society did not submit to the use of the veil. Undoubtedly, the habit of wearing a veil began in time to generalize and spread with the development of Islam. It was a matter of class discrimination in the first place. The isolation of women in time became common and began to generalize 
more that eventually, it became an everyday thing. The expressions used to refer to the veil were used as commendations to a woman or even a whole family. When queen Shajart Al-Durr ruled Egypt in the $7^{\text {th }}$ century, the preachers in mosques found no better expression for the flattery of the queen than to talk about her strict veil saying, "May Allah protect the deceased Khalil's mother, the righteous front, the queen of Muslims, the protector the world and religion, the woman with the beautiful veil and the venerable cover" [Ibid. P. 57].

The Quran mentioned that wearing a veil was for Mohammed's wives, not for other Muslim girls. Moreover, the veil was not part of the Arab tradition, but it was taken from other nations such as the Turks and Persians. Man sees Al-niqab as a form of fashion, and it was not used during the period of Mohammed by invoking Ibn Sireen, a scientist of the first century, who argues that al-niqab is nothing but fashion that was introduced in the second half of the first century. Finally, Mansour Fahmy believes that the main reason for the degeneration of the woman is her separation from the man and isolation from society. This is the summary of his dissertation through which he got his Ph.D. degree. It is the dissertation that he spent five years of his life and conscience on. However, he couldn't resist the intellectual terrorism that accused him of disbelief and atheism. Thus, he was isolated from his enlightenment role while abandoning all that he believed in. $\mathrm{He}$ said, "The good is that the woman does not get out of the house or the wifely and maternal field and to stay up to keep her husband comfortable. All evil lies in leading women to factories and shops as it is not compatible with God's laws and nature. Anything else a woman would ask for would be a fancy [Ibid. P. 59].

Mansour Fahmy started wondering how such accurate texts could lose their scientific value in some Islamic countries and how the isolation of women became so strict? And how could we interpret the traditions of some Islamic countries and social classes that prevented the appearance of a woman's face except in the presence of relatives and family members [Ibid. P. 66]?

Here Mansour Fahmy provides us with an answer saying, "The only explanation that could be recognized is the causes of the social system that contributed to the explanation of this prevention. Perhaps the development that led to the generalization of women's segregation was from the influence of the leading personality of the Prophet in his relationships with his wives. The verses of the Quran talk only about the Prophet's wives. It is worth mentioning that the following verse requires women to maintain a decent dressing, 'O Prophet! Ask your wives, daughters, and believing women to draw their cloaks over their bodies. In this way, it is more likely that they will be recognized 'as virtuous' and not be harassed. And Allah is All-forgiving, Most Merciful. (The Combined Forces) [Ibid. P. 69].

Mansour Fahmy emphasizes that the Prophet, prayers, and peace be upon Him, prevented men from being alone with women to avoid demonic seduction. Through all of these proofs, a norm originated and developed in some countries and spread among social classes, while in countries this norm or use has not well-developed. Some environments encouraged the use of the veil while opposed to the use of the 
veil. The reasons for these differences can be left to the historical and social analysis. Our goal is to recall the history of Mohammedan theories and Islamic morals [Ibid. P. 71].

Mansour Fahmy concludes his discussion of the veil saying, "To sum up, the Islamic religion and law have nothing to do with the call for the use of the veil (at least not directly). The systems that are committed to the veil are influenced by traditions, and this is if we could accurately clarify and discriminate between traditions and religions in the Islamic world. The history of the Islamic religion witnesses the difficulty of differentiating between a social perspective and a purely religious one. Islam is a religion and a way of life as it organized believers' lives in every smallest detail. Nevertheless, during Islam's historical development period, it made believers adjust themselves to the social necessities and the contradictory conditions of the woman's reality. When asked about the justification for using the veil, Muslims resort to their charter (i.e., agreement or unanimity) and the agreement of the Muslims on the prevention of the women from going out. This law of the Muslims is used as a shield and an essence in religion that would give legal weight to the Islamic Institution. If we consider things from the point of view of traditions and defend the idea of using the veil as an essential point of the Islamic religion, that would mean that we are not talking about a religion subject to change or development. The central pillar is the unanimity of the Muslims. It is better not to waste our time on a pointless debate and an empty circle. We should call things by their names and say that the use of the veil is the outcome of traditions and not religion [Ibid. P. 76].

Mansour Fahmy addressed many topics that are too long to explain, such as the case of slavery in law, slavery in traditions and realities, the effect of slavery on the status of the woman, the woman and the principles of the Islamic law and their practical effect upon the patriarchal system of Arabs, the woman and inheritance law, the powerlessness of the woman in front of the law, acceptance, and approval, the terms that can be mentioned in a marriage contract and the mutual rights and duties between married couples, divorce or breaking marital relations, dowry and so forth [Ibid. P. 87].

When Mansour Fahmy takes a historical look at the Islamic societies, he notices that the woman was the most person subjected to suppression and slavery in cities. The exuberant arrival of captive women (i.e., mothers) to these cities after the conquests turned the Arab world's infrastructure upside down after the emergence of Islam. Why? This is because the existence of a free woman is contrary to the existence of a slave woman (or a maid as known in the Classical Arabic language). In this way, men would fulfill all their desires and whims with the maid. On the other hand, their wives' only job is to give birth to children. We notice that in the Abbasi community, maids were more cultured and accessible than those called free women. Men in the past used to seek maids, they even guzzled them [Ibid. P. 89]. 
Mansour Fahmy further stresses by saying, "It is delusional to think that confusing and circumventing history will lead to the advancement of the woman's case. Mansour Fahmy clearly shows that history and the degradation of the Islamic religion led to the woman's submission to a new kind of slavery. Then he adds, "Although the woman had a theoretically inferior position, she had her position, and she was able to talk, think and move. If we compare the woman's position in the first Islamic community and her position in the contemporary Islamic community would be surprised by the huge difference between them. We can repeat the famous sentence of the French philosopher, Ernest Renan, which states," The Egyptian woman during the period of Mohammed does not resemble the dumb creature that fills the women chambers of the Ottomans. There is a gap between yesterday and today" [Ibid. P. 89].

At the end of this paper, words cannot express the due of this academic professor. I indeed said these words late, but many of those who call themselves professors do not know as much as this academic professor. Greetings to Dr. Mansour Fahmy who was and still represents a model of creative thinking and who knows how to deal with the world that surrounds him and keep up with its development. This is the model that we lack these days as many try to prove their loyalty to their homeland through isolationism, commitment, hatred of life, and becoming blind to the variety, multiplicity, and richness in the world [Ibid. P. 89].

\section{References}

[1] Ibrahim Madkour. Mansour Fahmy. Arabic Language Academy Magazine. 1962;14:343-354.

[2] Diab Mohammed Tawfik. The Late Dr. Mansour Fahmy. Arabic Language Academy Magazine in Cairo. 1962;14.

[3] Mahmoud Timor. 'Features and Branches': Snapshots of the Nation's Figures. Cairo: Al-Matbaa Al-Namouzagya; 1950.

[4] Taha Hussein. 'From a Distance'. Cairo: Hendawy's Foundation for Education and Culture; 2013.

[5] Ramadan Aida Ahmed. The Social Issue and Women's Rights in Mansour Fahmy's Thought, 1886-1959. Beirut; 2004.

[6] Mohammed Abd El-Raheem. Mansour Fahmy, Author of 'The Conditions of Women in Islam': Intellectual Enlightenment Attempt and its Miserable Fate. Al-Quds Al-Araby Journal. 2019:178.

[7] Al-Ahwany Ikram Ahmed Fouad. Mansour Fahmy. Faculty of Arts Journal. 1957 ;19(Pt 2).

[8] Ahmed Abdel-Haleem Attia. Mansour Fahmy and the Establishment of Social Morals. Philosophical Papers. 2016;(51).

[9] Mohammed Harby. The Status of Woman in Literature: Towards Freeing the Woman. Cairo; 1988.

[10] Mansour Fahmy: The Conditions of Women in Islam, Al-Gaml Publications, Cairo, 1913. 
About the author:

Mahmoud Mohammed Ali — Professor of Philosophy, Head of the Department of Philosophy, Faculty of Arts, Assiut University, Assiut, Egypt (e-mail: dr.mahmoudali55eg@gmail.com).

\title{
Мансур Фахми, основоположник исламского феминизма в современной египетской мысли
}

\author{
М.А. Махмуд \\ Асьютский университет, \\ Egypt,71515 Assiut, \\ dr.mahmoudali55eg@gmail.com
}

\begin{abstract}
Аннотация. Мансур Фахми (1886-1959), одна из самых драматичных фигур в современной арабской философской и социальной мысли. Он был реформатором и просветителем в современной арабской истории. Он также является основателем течения, которое подверглось жестоким нападкам, заставившим его надолго замолчать и уйти в укрытие. Однако эти события не смогли вытравить мнения и взгляды, появившиеся в начале двадцатого века в отношении женщин. Мансур Фахми первым использовал научную социологическую методологию для освещения исламского дискурса и его подходов к женщинам. Он стремился провести различие между религией и религиозным истеблишментом, между личностью пророка Мухаммада и тем, что позже возобладало в книгах по юриспруденции и смежных дисциплинах. Обсуждая вопрос о головном платке, Фахми пришел к выводу, что это продукт традиций и обычаев, что хиджаб не принадлежит исламской религии. Исламское право не имеет никакого отношения к хиджабу. Творчество Мансура Фахми пришлось на один из чувствительных этапов современной истории Египта, в котором столкнулись политическое, социальное, национальное, культурное и революционное. Все это, в свою очередь, определило интеллектуальное становление Мансура Фахми в битвах мысли и политики. Основная задача настоящей статьи - обрисовать истинные черты его личности и раскрыть реальность его интеллектуальных, социальных и политических позиций. Кроме того, автор статьи стремится отметить влияние философии на формирование личности Мансура Фахми и ее роль в закладке основ критического мировосприятия с его практическими, реформистскими и просветительскими аспектами.
\end{abstract}

Ключевые слова: Мансур Фахми, феминизм, исламский феминизм, Касим Амин, Таха Хусейн

\section{История статьи:}

Статья поступила 05.01.2021

Статья принята к публикации 10.03.2021

Для цитирования: Mahmoud M.A. Mansour Fahmy, Pioneer of Islamic Feminism in Modern Egyptian Thought // Вестник Российского университета дружбы народов. Серия: Философия. 2021. Т. 25. № 2. С. 202-212. DOI: 10.22363/2313-2302-2021-25-2-202-212

\section{Сведения об авторе:}

Махмуд Мохаммед Али - доктор философии, профессор, Асьютский университет, Асьют, Египет (e-mail: dr.mahmoudali55eg@gmail.com). 